\title{
Dopamine Modulation of GABA Tonic Conductance in Striatal Output Neurons
}

\author{
Megan J. Janssen, ${ }^{1,2}$ Kristen K. Ade, ${ }^{1,3}$ Zhanyan Fu, ${ }^{1}$ and Stefano Vicini ${ }^{1,2}$ \\ ${ }^{1}$ Department of Physiology and Biophysics, ${ }^{2}$ Department of Pharmacology, and ${ }^{3}$ Interdisciplinary Program in Neuroscience, Georgetown University School \\ of Medicine, Washington, DC 20007
}

We previously reported greater $G A B A_{A}$ receptor-mediated tonic currents in $D_{2}+$ striatopallidal than $D_{1}+$ striatonigral medium spiny neurons (MSNs) are mediated by $\alpha 5$-subunit-containing receptors. Here, we used whole-cell recordings in slices from bacterial artificial chromosome transgenic mice to investigate the link between subunit composition, phosphorylation, and dopamine receptor activation. Whole-cell recordings in slices from $\delta$-subunit knock-out mice demonstrate that while MSNs in wild-type mice do express $\delta$-subunitcontaining receptors, this receptor subtype is not responsible for tonic conductance observed in the acute slice preparation. We assessed the contribution of the $\beta 1$ - and $\beta 3$-subunits expressed in MSNs by their sensitivity to etomidate, an agonist selective for $\beta 2$ - or $\beta 3$ subunit-containing $\mathrm{GABA}_{\mathrm{A}}$ receptors. Although etomidate produced substantial tonic current in $\mathrm{D}_{2}+$ neurons, there was no effect in $\mathrm{D}_{1}+$ neurons. However, with internal PKA application or dopamine modulation, $\mathrm{D}_{1}+$ neurons expressed tonic conductance and responded to etomidate application. Our results suggest that distinct phosphorylation of $\beta 3$-subunits may cause larger tonic current in $\mathrm{D}_{2}+$ striatopallidal MSNs, and proper intracellular conditions can reveal tonic current in $\mathrm{D}_{1}+$ cells.

\section{Introduction}

The majority of neurons in the dorsal striatum, a major nucleus of the basal ganglia, are GABAergic projections called medium spiny neurons (MSNs) that express either dopamine $\mathrm{D}_{1}$ receptors $\left(D_{1}+\right)$ in the striatonigral pathway or dopamine $\mathrm{D}_{2}$ receptors $\left(\mathrm{D}_{2}+\right)$ in the stratopallidal pathway (Gerfen et al., 1990). Although these two cell types have similar basic physiological properties (Venance and Glowinski, 2003; Day et al., 2006; Taverna et al., 2008), we recently reported that $\mathrm{D}_{2}+$ MSNs have greater $\mathrm{GABA}_{\mathrm{A}}$ receptor-mediated tonic conductance than $\mathrm{D}_{1}+\mathrm{MSNs}$ (Ade et al., 2008). The subunits responsible for tonic conductance are fairly well established in other brain regions (Glykys and Mody, 2007), but those subunits that mediate tonic conductance in the striatum remain elusive.

$\mathrm{D}_{1}$ and $\mathrm{D}_{2}$ receptors are G-protein-coupled receptors (GPCRs) and regulate protein kinase A (PKA) phosphorylation via differing second messenger cascade systems. $\mathrm{D}_{1}$ receptors activate PKA, whereas $\mathrm{D}_{2}$ agonists inactivate PKA (Chen et al., 2006) through $G_{s} / G_{\text {olf }}$, and $G_{i / o}$ proteins, respectively (Stoof and Kebabian, 1984). PKA activity is essential to the physiological states of $\mathrm{GABA}_{\mathrm{A}}$ receptors as $\beta 1$ - and $\beta 3$-subunits are substrates for PKA-mediated phosphorylation (Moss et al., 1992; McDonald et al., 1998; Flores-Hernandez et al., 2000; Kittler et al.,

Received 0ct. 1, 2008; revised Feb. 17, 2009; accepted March 19, 2009.

This work was supported by National Institutes of Health Grants MH64797, F31NS058094, and T32DA007291. We thank Dr. David Lovinger at the National Institute on Alcoholism and Alcohol Abuse for providing the BACD ${ }_{2}$ EGFP mice and Dr. Gregg Homanics at the University of Pittsburgh for providing the $\delta-/-$ mice.

Correspondence should be addressed to Megan J. Janssen, Department of Physiology and Biophysics, BSB230 Georgetown University School of Medicine, 3900 Reservoir Road, Washington, DC 20007. E-mail: mjj34@georgetown.edu.

D01:10.1523/JNEUROSCI.4737-08.2009

Copyright $\odot 2009$ Society for Neuroscience $\quad$ 0270-6474/09/295116-11\$15.00/0
2005). However, the response to phosphorylation is subunitspecific, and $\beta 1$-subunit phosphorylation reduces, whereas $\beta 3$ subunit phosphorylation enhances GABAergic currents (McDonald et al., 1998; Nusser et al., 1999; Flores-Hernandez et al., 2000). Immunostaining studies show that all $\beta$-subunits are expressed in the rat striatum (Fritschy and Mohler, 1995; Pirker et al., 2000; Schwarzer et al., 2001), but single-cell PCR results suggest that MSNs do not express the $\beta 2$-subunit (Flores-Hernandez et al., 2000). Etomidate, a general anesthetic selective for the $\beta 2 / \beta 3 \mathrm{GABA}_{\mathrm{A}}$ subunits (Hill-Venning et al., 1997), should selectively enhance currents at $\beta 3$-subunit-containing receptors in MSNs and thus is an ideal tool to detect the presence of this subunit in MSNs. Therefore, all $\mathrm{GABA}_{\mathrm{A}}$ receptors in the striatum, both synaptic and extrasynaptic, may potentially be modulated by dopamine and its effects on PKA phosphorylation.

Tonic currents are of particular interest as they control excitability and are differentially expressed in $\mathrm{D}_{1}+$ and $\mathrm{D}_{2}+$ neurons. Inhibitory tonic conductance of the dorsal striatum controls the striatonigral and striatopallidal outputs for movement initiation and control. Since Parkinson's disease symptoms result from imbalances in these two pathways (Mallet et al., 2006), striatal tonic conductance may offer a potential therapeutic role in ameliorating physiological manifestations of Parkinsonian symptoms.

In this study, we further investigated the mechanisms underlying tonic conductance in striatal MSNs, and we explored the interactions between dopamine agonists, PKA phosphorylation, and tonic inhibition in MSNs. Our results show that differences in tonic currents are attributable to differential subunit expression patterns and basal phosphorylation rates. Tonic conductance in $\mathrm{D}_{2}+$ MSNs is attributable to extrasynaptic and basally phosphorylated $\beta 3$-subunit-containing $\mathrm{GABA}_{\mathrm{A}}$ receptors, but $\mathrm{D}_{1}+$ MSNs also exhibit tonic conductances via phosphorylated 
$\beta 3$-subunits with internal PKA application or $\mathrm{D}_{1}$ receptor stimulation. Our studies also suggest that dopamine exhibits influence on cell excitability through these mechanisms.

\section{Materials and Methods}

Animals. Bacterial artificial chromosome (BAC) $\mathrm{D}_{2}$-enhanced green fluorescent protein (EGFP) mice (Gong et al., 2003) (provided by David Lovinger, National Institute on Alcohol Abuse and Alcoholism, Bethesda, MD) were crossed with C57BL/6 mice. Slices were prepared from postnatal day 15-23 male and female mice as in Ade et al. (2008), unless otherwise noted. MSNs were classified as being either dopamine $\mathrm{D}_{2}$ receptor positive $\left(\mathrm{D}_{2}+\right)$ or negative by their expression of EGFP. Because previous studies have demonstrated that MSNs express either dopamine $\mathrm{D}_{1}$ or $\mathrm{D}_{2}$ receptors (Gerfen et al., 1990; Day et al., 2006), MSNs negative for EGFP in the BAC $D_{2}$ EGFP mice were presumed to be $\mathrm{D}_{1}+$ and those expressing EGFP as $\mathrm{D}_{2}+. \delta$-subunit knock-out mice (provided by Dr. Gregg Homanics, Department of Anesthesiology, University of Pittsburgh, Pittsburgh, PA) were genotyped with Southern blot as described in Mihalek et al. (1999).

Slice preparation. Mice were killed by decapitation in agreement with the guidelines of the American Veterinary Medical Association Panel on Euthanasia and the Georgetown University Animal Care and Use Committee. The whole brain was removed and placed in an ice-cold slicing solution containing (in mM) $85 \mathrm{NaCl}, 2.5 \mathrm{KCl}, 1 \mathrm{CaCl}_{2}, 4 \mathrm{MgCl}_{2}, 1$ $\mathrm{NaH}_{2} \mathrm{PO}_{4}, 25 \mathrm{NaHCO}_{3}, 25$ glucose, 75 sucrose (all from Sigma). Corticostriatal coronal slices $(250 \mu \mathrm{m})$ were prepared using a Vibratome 3000 Plus Sectioning System (Vibratome) and were incubated in slicing solution at $32^{\circ} \mathrm{C}$ for $30 \mathrm{~min}$. Slices recovered for $30 \mathrm{~min}$ at $32^{\circ} \mathrm{C}$ in artificial CSF (aCSF) containing (in mM) $124 \mathrm{NaCl}, 4.5 \mathrm{KCl}, 1.2 \mathrm{Na}_{2} \mathrm{HPO}_{4}, 26$ $\mathrm{NaHCO}_{3}, 2 \mathrm{CaCl}_{2}, 1 \mathrm{MgCl}_{2}$, and 10 dextrose at $305 \mathrm{mOsm}$. During experiments, slices were submerged and continuously perfused $(2-3 \mathrm{ml} /$ $\mathrm{min}$ ) with aCSF at room temperature, $22-24^{\circ} \mathrm{C}$, unless otherwise noted. All solutions were maintained at $\mathrm{pH} 7.4$ by continuous bubbling with $95 \% \mathrm{O}_{2}, 5 \% \mathrm{CO}_{2}$.

Slices were visualized under an upright microscope (E600FN; Nikon) equipped with Nomarski optics and an electrically insulated $60 \times$ waterimmersion objective with a long working distance $(2 \mathrm{~mm})$ and high numerical aperture (1.0). Recording electrodes were pulled on a vertical pipette puller from borosilicate glass capillaries (Wiretrol II; Drummond) and filled with Cs Cl-based internal recording solution $(\mathrm{CsCl}$ internal) containing (in mM) $145 \mathrm{CsCl}, 10 \mathrm{HEPES}, 5 \mathrm{ATP} . \mathrm{Mg}, 0.2 \mathrm{GT}$ P.NA, and 10 EGTA, adjusted to pH 7.2 with $\mathrm{CsOH}$. In K-gluconatebased internal solutions (K-gluconate internal), $\mathrm{CsCl}$ was replaced with equimolar K-gluconate. In some experiments, cell impermeable protein phosphorylation modulators were supplemented in the internal solution. A bovine catalytic subunit PKA $(50-75 \mu \mathrm{g} / \mathrm{ml}$; Sigma) and PKA inhibitory peptide (PKI; $20 \mu \mathrm{M}$; Sigma H2N-TYADFIASGRTGRRNAIamide) were initially prepared in water and maintained at $-20^{\circ} \mathrm{C}$. The PKA stock solution was used within $3 \mathrm{~d}$ of reconstitution according to manufacturer specifications.

Whole-cell recordings. Single and dual voltage-clamp recordings were performed using the whole-cell configuration of the patch-clamp technique at a pipette voltage of $-60 \mathrm{mV}$ using the Axopatch 200B and $1 \mathrm{D}$ amplifiers (Molecular Devices). Access resistance was monitored during the recordings, and experiments with $>20 \%$ change were discarded. The baseline membrane potential for current-clamp recordings was set at $-70 \mathrm{mV}$ before each series of current step injection protocols. Rheobase current was defined as the first current step, within a series of increasing $20 \mathrm{pA}$ steps, that elicited an action potential.

Stock solutions of bicuculline methobromide (BMR), tetrodotoxin (TTX), 4,5,6,7-tetrahydroisoxazolo $\{5,4$-c $\}$ pyridine-3-ol, (THIP), SKF81297, quinpirole, sulpiride, SCH 23390, and GABA (all from Sigma) were prepared in water. Etomidate (Sigma) was dissolved in dimethylsulfoxide $(<0.0001 \%$ final concentration). All stock solutions were diluted to the desired concentration in aCSF and applied locally through a Y tube (Murase et al., 1989) modified for optimal solution exchange in brain slices (Hevers and Luddens, 2002).

Currents were filtered at $2 \mathrm{kHz}$ with a low-pass Bessel filter and digi-
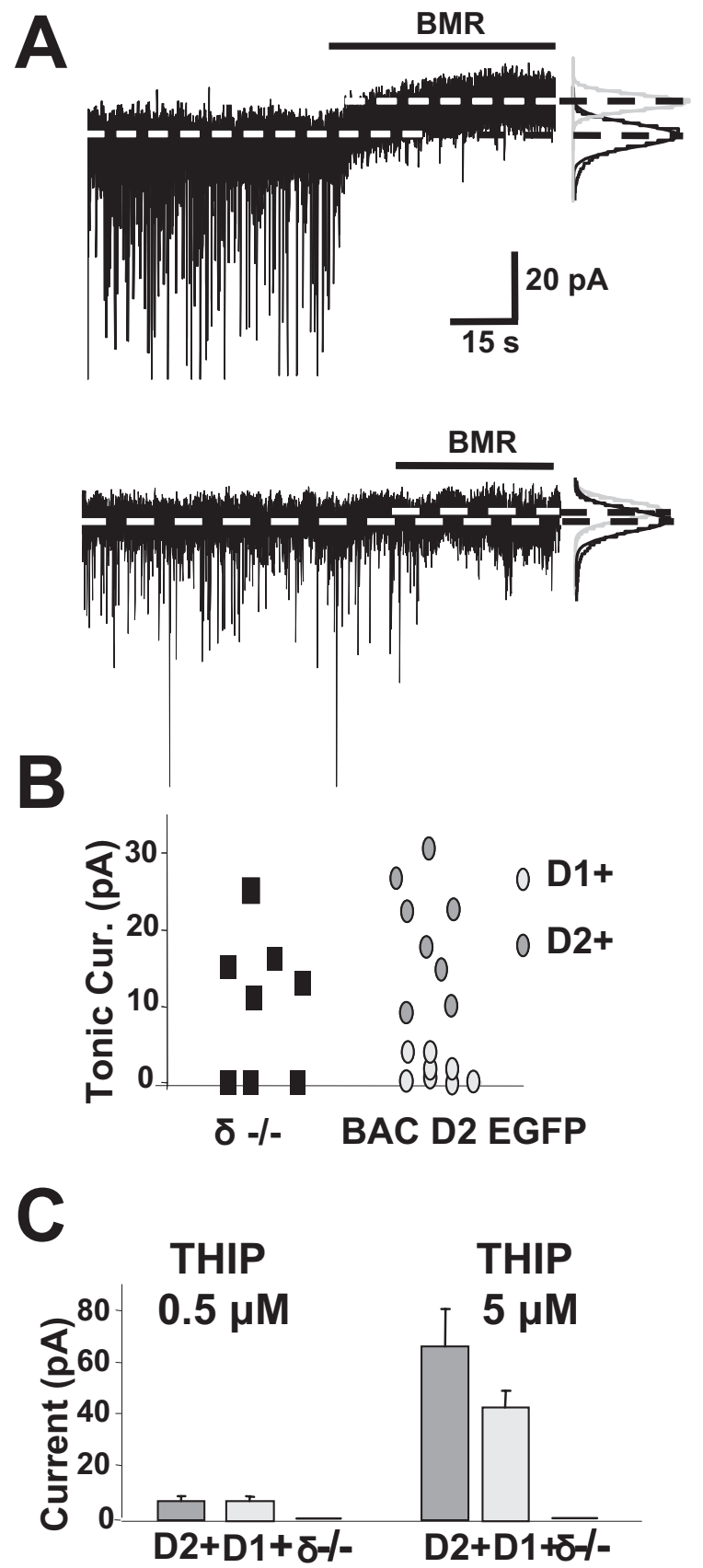

Figure 1. The $\delta$-subunit does not contribute to tonic current. $\boldsymbol{A}$, Illustrative records from MSNs in a $\delta-/-$ mouse showing differential block in tonic current with BMR application. Right, all-points histogram and Gaussian fit from each segment. $\boldsymbol{B}$, Summary results show that the tonic current expression in a $\delta-/-$ mouse resembled the pattern of tonic current expressed in $D_{2}+$ and $D_{1}+$ MSN from BAC $D_{2}$ EGFP mice, suggesting that the $\delta$-subunit is not responsible for the differential tonic currents between $\mathrm{D}_{2}+$ and $\mathrm{D}_{1}+$ MSN. C, THIP application in the presence of TTX did not induce tonic current in $\delta-/-\operatorname{MSNs}(n=6)$, as it did in both $\mathrm{D}_{2}+(n=17)$ and $\mathrm{D}_{1}+(n=6)$ MSNs from BAC $\mathrm{D}_{2}$ EGFP mice, confirming that the $\delta$-subunit is not present.

tized at $5-10 \mathrm{kHz}$ using a personal computer equipped with Digidata 1322A data acquisition board and pCLAMP9 software (both from Molecular Devices). Off-line data analysis, curve fitting, and figure preparation were performed with Clampfit 9 software (Molecular Devices). Spontaneous and miniature IPSCs (sIPSCs and mIPSCs) were identified using a semiautomated threshold based minidetection software (Mini Analysis; Synaptosoft) and were visually confirmed as in Ade et al. (2008). Briefly, IPSC averages were based on more than 60 events, and 
$\beta 1$

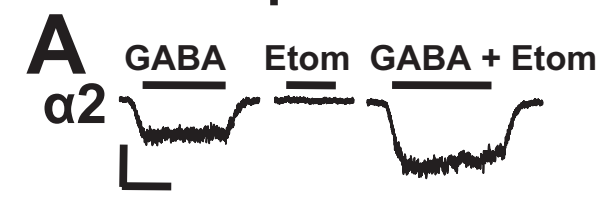

B
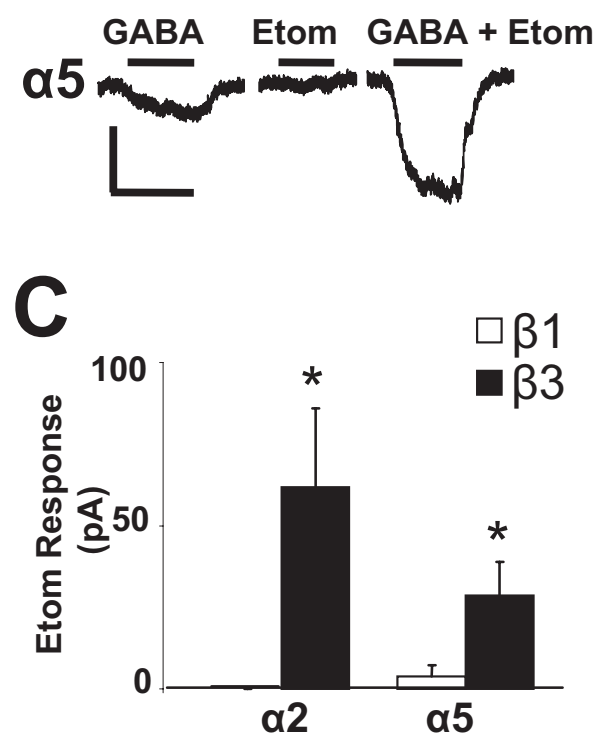

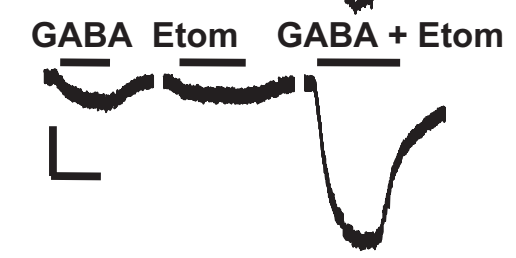

B3

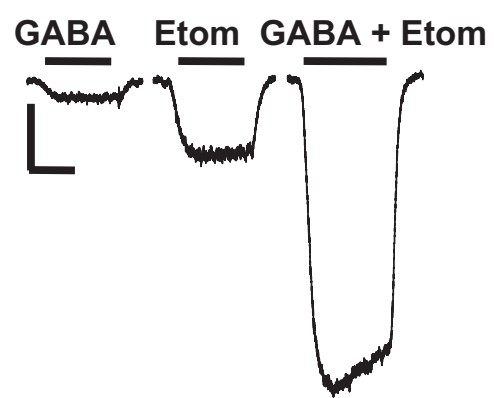

D

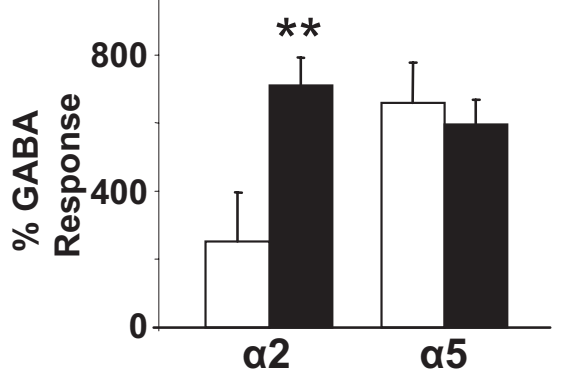

Figure 2. Etomidate's direct effects are selective for $\beta 3$-containing receptors. $A$, Representative currents from HEK 293 cells transfected with $\alpha 2 \beta 1 \gamma 2$ or $\alpha 2 \beta 3 \gamma 2$ receptors with GABA (3 $\mu \mathrm{m}$ for $\alpha 2 \beta 1 \gamma 2,1 \mu \mathrm{m}$ for $\alpha 2 \beta 3 \gamma 2)$ and etomidate (3 $\mu \mathrm{M})$ application, showing $\beta 3$-subunit selectivity for direct and potentiating effects. Calibration: $200 \mathrm{pA}, 10 \mathrm{~s}$. B, Representative currents from HEK 293 cells transfected with $\alpha 5 \beta 1 \gamma 2$ or $\alpha 5 \beta 3 \gamma 2$ receptors with GABA ( $250 \mathrm{~nm}$ for $\alpha 5 \beta 1 \gamma 2$ and $\alpha 5 \beta 3 \gamma 2$ ) and etomidate $(3 \mu \mathrm{m})$ application, showing $\beta 3$-subunit selectivity for direct effects only. Calibration: $50 \mathrm{pA}, 10 \mathrm{~s}$. C, Summary of etomidate's direct effects on striatally relevant $\mathrm{GABA}_{A}$ receptors $(\alpha 2 \beta 1 \gamma 2, n=6 ; \alpha 2 \beta 3 \gamma 2, n=10 ; \alpha 5 \beta 1 \gamma 2, n=5$; $\alpha 5 \beta 3 \gamma 2, n=7)$. $D$, Summary of etomidate's potentiating effects on GABA currents evoked by EC10 concentrations of GABA on each receptor type ( $\alpha 2 \beta 1 \gamma 2, n=4 ; \alpha 2 \beta 3 \gamma 2, n=5 ; \alpha 5 \beta 1 \gamma 2, n=13 ; \alpha 5 \beta 3 \gamma 2, n=6)$.

the decay kinetics were determined using double exponential curve fittings and reported as weighted time constants (tau). All detected events were used for event frequency analysis, but superimposing events were eliminated for the amplitude, rise time, and decay kinetic analysis. Tonic current measurements were made as in Ade et al. (2008). Briefly, an all-points histogram was plotted for a $10 \mathrm{~s}$ period immediately before and during BMR application. Tonic currents are represented as the change in baseline amplitude. When PKA or PKI was included in the internal solution, events were analyzed at least $4 \mathrm{~min}$ after break-in to allow the peptide to function and equilibrate with the internal components of the cell.

Statistical significance was determined using the two-tailed Student's $t$ test (unpaired when comparing two populations of cells and paired when comparing results within the same cell). All values are expressed as mean \pm SEM. In all figures, ${ }^{*} p<0.05,{ }^{* *} p<0.005$, and ${ }^{* * *} p<0.0005$.

Human embryonic kidney 293 cells and transfection. Human embryonic kidney 293 (HEK 293) cells (American Type Culture Collection; CRL1573) were grown in minimal essential medium (Invitrogen), supplemented with $10 \%$ fetal bovine serum, 100 units $/ \mathrm{ml}$ penicillin, and 100 units $/ \mathrm{ml}$ streptomycin (all from Invitrogen) in a $5 \% \mathrm{CO}_{2}$ incubator at $36^{\circ} \mathrm{C}$. Growing cells were dispersed with trypsin and seeded at $\sim 2 \times 10^{5}$ cells $/ 35 \mathrm{~mm}$ dish in $2 \mathrm{ml}$ of culture medium on $12 \mathrm{~mm}$ glass coverslips coated with poly-D-lysine. The cells were transfected with rat $\mathrm{GABA}_{\mathrm{A}}$ receptor subunit cDNAs, because of their high homology to mouse re- ceptors, and EGFP using calcium phosphate precipitation. The following plasmid combinations were used: $\alpha 2 \beta 1 \gamma 2, \alpha 2 \beta 3 \gamma 2, \alpha 5 \beta 1 \gamma 2$, and $\alpha 5 \beta 3 \gamma 2$ (all a gift from Peter Seeburg, University of Heidelberg, Heidelberg, Germany) at a ratio of 1:1:4. Mixed plasmids (5 $\mu \mathrm{g}$ total) were added to the dish containing $2 \mathrm{ml}$ culture medium for $8-12 \mathrm{~h}$ at which point the media was refreshed. The cells were used for electrophysiological recordings $2-3 \mathrm{~d}$ after transfection.

\section{Results}

$\mathrm{GABA}_{\mathrm{A}}$ receptors in MSNs

Our previous study suggested that the major differences in tonic current between $\mathrm{D}_{1}+$ and $\mathrm{D}_{2}+$ MSNs lies in the presence of $\alpha 5$-containing receptors in $\mathrm{D}_{2}+$ neurons (Ade et al., 2008). Additionally, both $\mathrm{D}_{1}+$ and $\mathrm{D}_{2}+$ MSNs had similar sensitivity to low doses of THIP, a $\delta$-subunitcontaining $\mathrm{GABA}_{\mathrm{A}}$ receptor superagonist (Brown et al., 2002), suggesting that both MSN subtypes express the $\delta$-subunit. To support these results, we performed whole-cell recordings in MSNs in striatal slices prepared from $\delta$-subunit-/- mice. We observed a BMR-sensitive current in a subset of the cells (Fig. 1A), and a similar scatter in tonic current expression by distinct MSN subtypes in $\delta-/-$ and $\mathrm{BAC} \mathrm{D}_{2}$ EGFP mice (Fig. $1 B$ ), supporting the hypothesis that although the $\delta$-subunit is present in MSNs, it is not responsible for tonic current in the age range investigated. However, as shown in Figure $1 C$, MSNs from these mice lost responsiveness to low doses of THIP as previously reported in hippocampal neurons from $\delta-/-$ mice (Glykys et al., 2008).

Because the magnitude of tonic current was not different between BAC $\mathrm{D}_{2}$ EGFP mice and the $\delta-/-$ mouse, we hypothesized that tonic current in $\mathrm{D}_{2}+$ cells is mediated by $\alpha 5 \beta \mathrm{x} \gamma 2$ receptors. Both $\beta 1$ - and $\beta 3$-subunits are targets for PKA phosphorylation, and their presence may have robust effects on tonic current. To study the relative $\beta$-subunit expression and function in striatal $\mathrm{D}_{2}+$ and $\mathrm{D}_{1}+$ cells, we used etomidate $(3 \mu \mathrm{M})$, a general anesthetic specific for the $\beta 2 / \beta 3$ subunits of the $\mathrm{GABA}_{\mathrm{A}}$ receptor (Belelli et al., 1996; Herd et al., $2008)$. The $\beta$-subunit selectivity of etomidate was initially demonstrated in recombinant systems with $\alpha 1 \beta 1 \gamma 2$ - and $\alpha 1 \beta 3 \gamma 2$ subunit combinations (Slany et al., 1995; Sanna et al., 1997). Subsequently, the differential effects of etomidate between $\beta 1$ and $\beta 2$-subunits were shown to be maintained in receptors that contained the $\alpha 1-, \alpha 2-, \alpha 3-$, or $\alpha 6$-subunits (Hill-Venning et al., 1997). In addition, a study using $\alpha 5-/-$ mice demonstrated that etomidate mediates amnestic but not sedative-hypnotic effects by selectively activating the tonic, not phasic, $\mathrm{GABA}_{\mathrm{A}}$ currents (Cheng et al., 2006). Because the specificity of this drug has not been tested in recombinant systems that include the $\alpha 5$-subunit, we investigated the efficacy of etomidate in HEK 293 cells transfected with striatally relevant (Fritschy and Mohler, 1995; Pirker et al., 2000; Schwarzer et al., 2001) combinations of $\alpha$ - and $\beta$-subunits together with $\gamma 2$ : $\alpha 2 \beta 1 \gamma 2, \alpha 2 \beta 3 \gamma 2, \alpha 5 \beta 1 \gamma 2$, and $\alpha 5 \beta 3 \gamma 2$. 


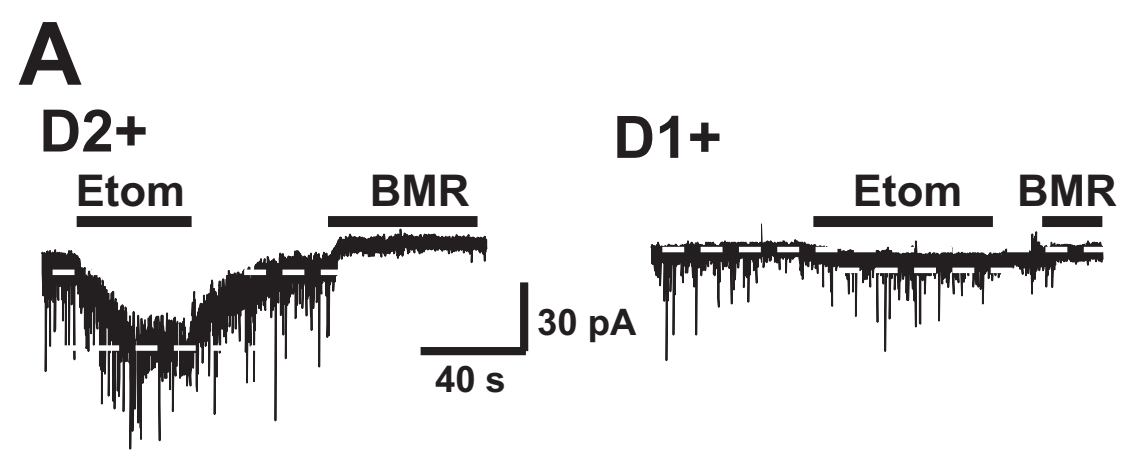

B
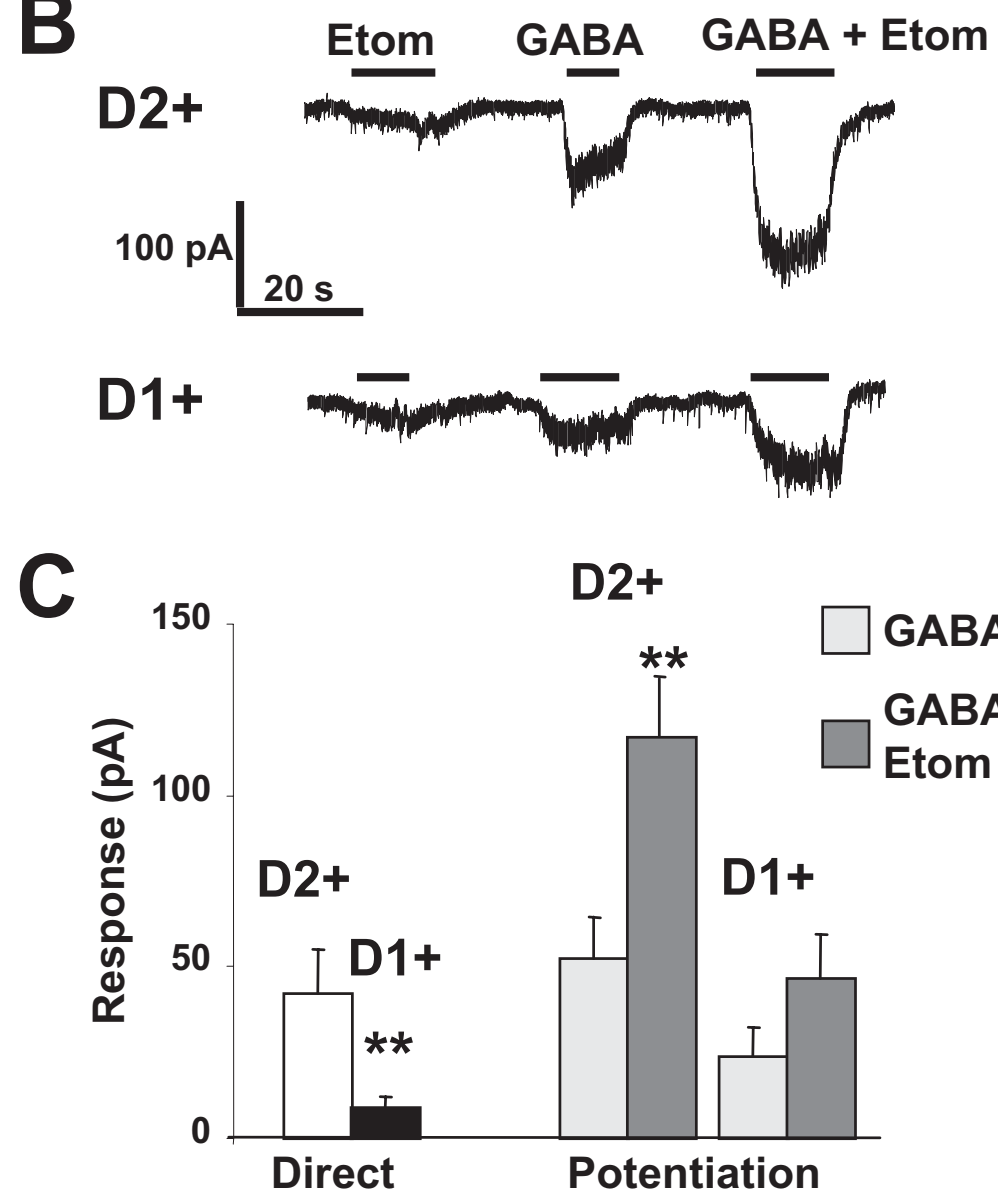

Figure 3. Etomidate selectively activates tonic receptors in $D_{2}+M S N s$. $A$, Representative current traces of a $D_{2}+$ and a $D_{1}+$ MSN showing etomidate-elicited currents in the $D_{2}+$, but not the $D_{1}+$, MSN. $B$, Representative current traces of two individual MSNs, showing the direct effect of etomidate $(3 \mu \mathrm{M})$, response to $1 \mu \mathrm{MGABA}$, and etomidate's $(3 \mu \mathrm{M})$ potentiating effects with $1 \mu \mathrm{MGABA}$, all in $0.5 \mu \mathrm{M}$ TTX. C, Summary data of etomidate's direct $\left(n=10, \mathrm{D}_{2}+; n=8, \mathrm{D}_{1}+\mathrm{MSN}\right)$ and potentiating $(n=7$, $\mathrm{D}_{2}+; n=5, \mathrm{D}_{1}+\mathrm{MSN}$ ) effects to $1 \mu \mathrm{M} G A B A$ on $\mathrm{D}_{2}+$ and $\mathrm{D}_{1}+$ tonic current.

In these cells, we tested both direct activation of the recombinant $\mathrm{GABA}_{\mathrm{A}}$ receptors and modulation of GABA responses with etomidate. The general anesthetic produced significant current in cells expressing $\beta 3$-containing $\mathrm{GABA}_{\mathrm{A}}$ receptors but failed to directly activate those cells transfected with the $\beta 1$-subunit (Fig. $2 A, B)$, regardless of the $\alpha$-subunit. In each cell studied, we tested the response to multiple GABA concentrations and compared them to a saturating dose of GABA ( $3 \mathrm{mM}$ ) to select the EC10 used to compare etomidate's direct effects with GABA potentiation. Figure 2, $A$ and $B$, shows examples of direct and potentiating effects in transfected cells with $\alpha 2 \beta 1 \gamma 2, \alpha 2 \beta 3 \gamma 2, \alpha 5 \beta 1 \gamma 2$, and $\alpha 5 \beta 3 \gamma 2$ receptors. The summary of the results obtained with different $\alpha$-subunits tested are shown in Figure 2, $C$ and $D$. Etomidate robustly potentiated GABA current produced by $\beta 3$-containing receptors and had a slight potentiating effect on those produced by $\beta 1$-containing receptors when expressed with the $\alpha 2$-subunit. However, etomidate produced similar potentiating responses in $\beta 1$ - and $\beta 3$ containing receptors when combined with the $\alpha 5$-subunit. We concluded from these experiments that the direct agonist actions of etomidate are selective for receptors containing $\beta 3$-subunits but not those containing $\beta 1$-subunits.

Interestingly, although the maximal GABA response was comparable between the two $\alpha 2$-containing recombinant receptors, the response to $3 \mu \mathrm{M}$ GABA was $7 \pm 3 \%(n=5)$ of the maximal response in $\alpha 2 \beta 1 \gamma 2$ cells and $31 \pm 7 \%(n=10)$ of the maximal response in $\alpha 2 \beta 3 \gamma 2$ cells $(p<$ $0.05)$. This differential affinity for GABA was not apparent in the $\alpha 5$-containing transfected receptors for any concentrations of GABA (data not shown). However, these receptors had higher sensitivity to GABA than $\alpha 2$-containing receptors (1 $\mu \mathrm{M}$ GABA; $\alpha 5 \beta 1 \gamma 2,25 \pm 4 \%$ of maximal response, $n=18 ; \alpha 5 \beta 3 \gamma 2,17 \pm 2 \%$ of maximal response, $n=23$ ).

Because striatal MSNs presumably do not express the $\beta 2$-subunit (FloresHernandez et al., 2000), etomidate's effects in these neurons are an indication of the presence of $\beta 3$-subunit. In Figure $3 A$, we show individual traces from a $\mathrm{D}_{2}+$ and a $D_{1}+M S N$, and as summarized in Figure $3 C$ (left), etomidate produced substantial tonic current in the $\mathrm{D}_{2}+$ neurons, whereas the response in $\mathrm{D}_{1}+$ MSNs was significantly smaller and did not differ from baseline. As GABAergic interneurons may express the $\beta 2$-subunit (Yan and Surmeier, 1997), we repeated these experiments in $0.5 \mu \mathrm{M}$ TTX to block interneuron activity, given that spontaneous activity of these neurons contributes to tonic current in MSNs (Ade et al., 2008). In TTX, etomidate produced $34 \pm 6 \mathrm{pA}(n=16)$ of current in $\mathrm{D}_{2}+$ MSNs and just $10 \pm 2 \mathrm{pA}(n=$ 13) in $\mathrm{D}_{1}+\mathrm{MSNs}(p<0.05)$. Tonic current in MSNs is produced by unknown concentrations of ambient GABA. Thus, etomidate effects could be attributable to a combination of direct activation and potentiation of GABA channels. However, ambient GABA is at such low concentrations that any potentiation effect will be minimal. Thus, if the direct activation predominates, it implies that $\beta 3$ subunit expression is greater in $D_{2}+$ than $D_{1}+$ MSN.

As $\mathrm{D}_{1}+$ MSNs do not display endogenous tonic current, we compared the effects of the anesthetic on exogenously applied GABA to determine the potentiating action of etomidate in both cell types. Figure $3 B$ shows examples of the etomidate potentia- 
tion of current elicited by $1 \mu \mathrm{M}$ GABA applications in the presence of $0.5 \mu \mathrm{M}$ TTX in individual $\mathrm{D}_{2}+$ and $\mathrm{D}_{1}+$ MSNs. Even in these experimental conditions, the $\mathrm{D}_{2}+$ MSN exhibited greater potentiating etomidate effects compared with the $\mathrm{D}_{1}+$ MSN. Similar to etomidate's direct effects, the GABA potentiation with etomidate was significantly larger than the $1 \mu \mathrm{M}$ GABA response alone in the $\mathrm{D}_{2}+$, but not the $\mathrm{D}_{1}+\mathrm{MSN}$ (Fig. 3C, right).

To assess the etomidate response on synaptic $\mathrm{GABA}_{\mathrm{A}}$ receptors, we investigated changes in mIPSCs in the two MSN subtypes. Using $\mathrm{CsCl}$ internal solution to enhance detection of mIPSCs from distal locations, basic properties of mIPSCs did not differ between MSN subtypes as reported previously (Ade et al., 2008). Figure $4 A$ shows examples of mIPSCs recorded in the presence and absence of $3 \mu \mathrm{M}$ etomidate together with the overlapping averaged mIPSCs. Figure $4 B$ summarizes changes in frequency, amplitude, decay, and rise time of mIPSCs obtained in the two cell types. These data suggest that $\mathrm{D}_{2}+$ and $\mathrm{D}_{1}+$ cells have a similar complement of $\beta 3$-subunits at synaptic locations.

\section{PKA regulates MSN tonic current}

Although differential extrasynaptic expression of the $\beta 3$-subunit may yield increased tonic conductance in the $\mathrm{D}_{2}+$ MSNs, PKA phosphorylation may be an important mediator and increase the number of tonically active GABA channels with distinct subunit combinations. To determine the effect of PKA on $\mathrm{D}_{2}+$ and $\mathrm{D}_{1}+\mathrm{MSN}$ tonic conductances, we added the catalytic subunit of PKA $(50-75 \mu \mathrm{g} / \mathrm{ml})$ to the $\mathrm{CsCl}$ internal solution to measure the effects of postsynaptic PKA modulation without affecting presynaptic release probability. Figure $5 \mathrm{~A}$ shows that with inclusion of the PKA catalytic subunit, a $D_{1}+$ neuron had an increased BMR-sensitive tonic current, whereas the tonic current was smaller in a $\mathrm{D}_{2}+\mathrm{MSN}$. Under conditions that promote PKA phosphorylation, the $\mathrm{D}_{1}+$ neurons express tonic current, suggesting that phosphorylation is an important regulator of tonic conductance in striatal MSNs. Figure $5 C$ shows that internal PKA application did not alter the decay times of mIPSCs for $\mathrm{D}_{2}+$ or $\mathrm{D}_{1}+$ neurons.

Based on our hypothesis that tonic current is mediated by $\beta 3$-containing receptors, we investigated the effect of etomidate on the magnitude of tonic current in $\mathrm{D}_{2}+$ and $\mathrm{D}_{1}+$ neurons with internal PKA application. In a simultaneous dual recording of a $\mathrm{D}_{2}+$ and $\mathrm{D}_{1}+\mathrm{MSN}$ with internal PKA application (Fig. $5 D$ ), etomidate uncovered tonic current in the $\mathrm{D}_{1}+\mathrm{MSN}$, but etomidate responses in $\mathrm{D}_{2}+$ neurons were slightly smaller compared with control conditions (Fig. 5D,E). Again, these experiments were repeated in TTX $(0.5 \mu \mathrm{M})$ to block interneuron activity, and the same observations were made: internal PKA application increased the $\mathrm{D}_{1}+$ etomidate response $(21 \pm 4.4 \mathrm{pA}, n=10, p=$ 0.07 ), whereas the $\mathrm{D}_{2}+$ response decreased ( $26 \pm 5.1 \mathrm{pA}, n=8$, $p<0.05)$. Etomidate responses did not differ between the $\mathrm{D}_{2}+$ and the $D_{1}+$ MSNs with internal PKA application, indicating that the two MSN subtypes have a similar population of $\beta 3$ containing receptors. Because etomidate revealed a tonic current in $\mathrm{D}_{1}+$ cells with internal PKA application, it appears that a phosphorylated $\beta 3$-subunit is responsible, in part, for $\mathrm{GABA}_{\mathrm{A}}$ tonic conductance in both MSN subtypes.

To verify that endogenous PKA phosphorylation is involved in mediating $\mathrm{D}_{2}+\mathrm{MSN}$ tonic current, we supplemented the PKI $(20 \mu \mathrm{M})$ in the internal solution and measured the changes in tonic current compared with control conditions. PKI attenuated the $\mathrm{D}_{2}+\mathrm{MSN}$ tonic current $(5.0 \pm 1.0 \mathrm{pA}, n=7$ compared with $26 \pm 3.6 \mathrm{pA}, n=14, p<0.0005)$ while not affecting the tonic current in $\mathrm{D}_{1}+\mathrm{MSNs}(4.8 \pm 1.9 \mathrm{pA}, n=4$ compared with $3.4 \pm$ $0.4 \mathrm{pA}, n=11, p=0.3)$. PKI had no discernible effects on synaptic receptors as sIPSC decay, amplitude, or frequency did not change $\left(\mathrm{D}_{2}+, n=13 ; \mathrm{D}_{1}+, n=4\right)$.

\section{Dopamine modulation of GABA currents}

$\mathrm{D}_{1}$ and $\mathrm{D}_{2}$ GPCRs contribute to the phosphorylation cascade in MSNs. Although $\mathrm{D}_{1}$ activation promotes phosphorylation, the $\mathrm{D}_{2}$ receptor acts to reduce PKA activity and increase activity of protein phosphatase 1 through DARPP-32 (Stoof and Kebabian, 1984). Thus, dopamine release in the striatum should promote PKA activity in $D_{1}+$ MSNs while inhibiting PKA activity in $\mathrm{D}_{2}+$ MSNs. Therefore, we sought to determine basal dopamine levels 


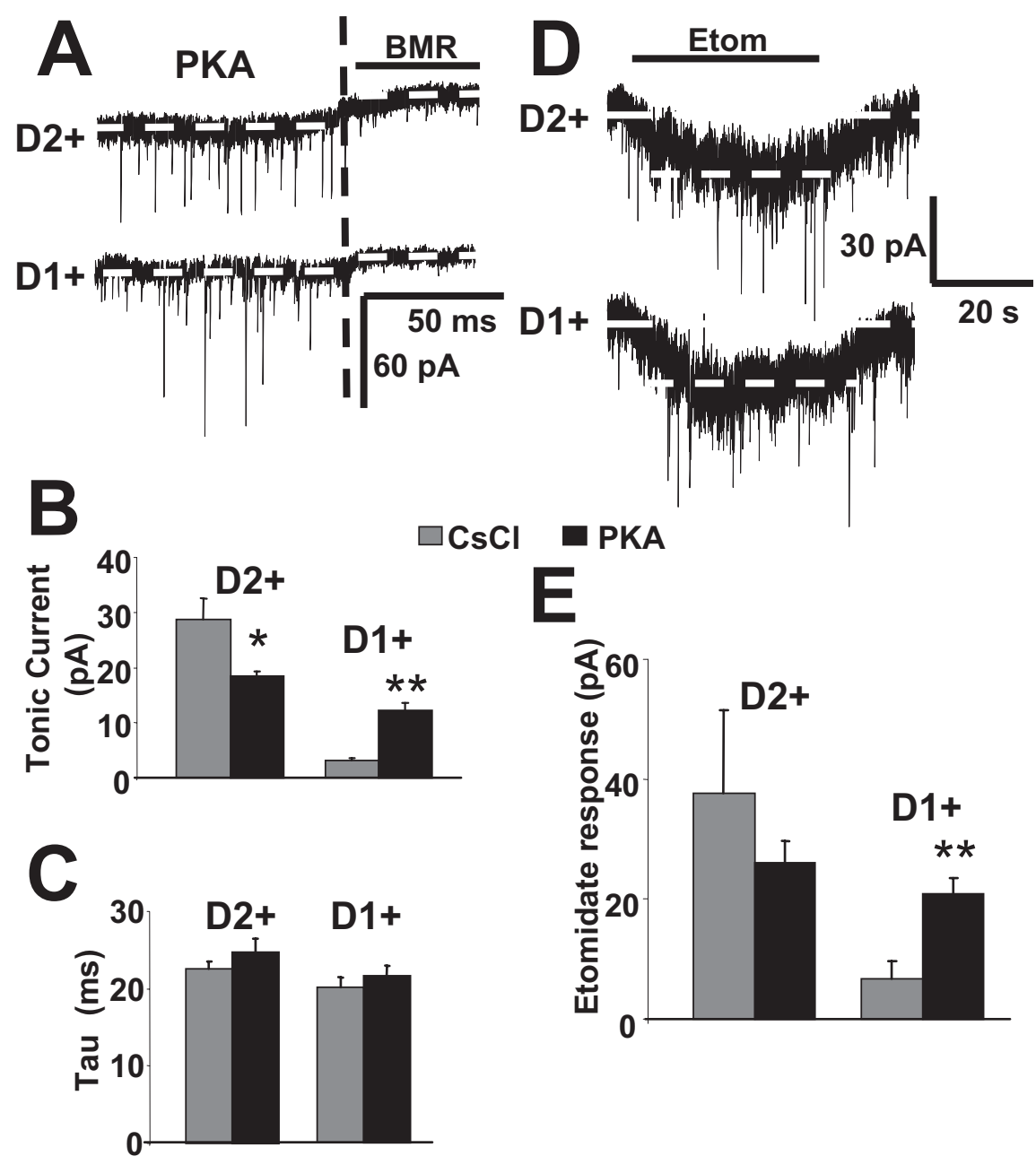

Figure 5. Internal PKA application modulates tonic current. $A$, Representative traces of two individual MSNs where PKA was supplemented in the internal solution, showing BMR-sensitive tonic current in both cells. $B$, Summary graph for tonic current in $D_{2}+$ and $D_{1}+$ MSN in control conditions $\left(D_{2}+, n=12 ; D_{1}+, n=10\right)$ and in conditions with internal PKA application $\left(D_{2}+\right.$, $\left.n=10 ; D_{1}+, n=15\right)$. C, Summary graph of the changes in mIPSC decay with internal PKA application $\left(D_{2}+, n=14 ; D_{1}+, n=\right.$ 21) compared with control $\left(D_{2}+, n=31 ; D_{1}+, n=26\right)$. $D$, Representative traces from simultaneous dual recording of $D_{1}+-$ $D_{2}+$ MSNs, showing etomidate responses with internal PKA application. $E$, Summary graph for current induced by etomidate with internal PKA application. The $D_{1}+$ etomidate response increases significantly with internal PKA application, whereas $D_{2}+$ responses decrease slightly ( $n=10$ and $8, D_{2}+$ and $D_{1}+$, respectively, in $\mathrm{CsCl} ; n=9$ and 12 in PKA).

in our slice preparation as free dopamine will affect our system in drastically different ways. In whole-cell recordings from four $\mathrm{D}_{2}+\mathrm{MSNs}$, the $\mathrm{D}_{2}$ antagonist sulpiride $(2 \mu \mathrm{M})$ did not affect tonic or phasic currents (data not shown). Likewise, recordings from $\mathrm{D}_{1}+\mathrm{MSN}$ in SCH $23390(10 \mu \mathrm{M})$ also did not affect tonic or phasic currents $(n=5)$. These results suggest that dopamine is not present in our recording conditions in young mice or that it is present in such low concentrations that it does not activate $D_{1}$ and $\mathrm{D}_{2}$ receptors.

Because modulating internal phosphorylation altered the tonic GABA currents in MSNs, we sought to determine if dopamine also affects the phosphorylation cascade, yielding altered GABA receptor function in $\mathrm{D}_{2}+$ and $\mathrm{D}_{1}+$ neurons. First, we applied the $\mathrm{D}_{2}$-like agonist quinpirole $(10 \mu \mathrm{M})$ to both $\mathrm{D}_{2}+$ and $\mathrm{D}_{1}+\mathrm{MSN}$ followed by application of BMR $(25 \mu \mathrm{M})$ after recording for $\sim 5$ min to allow the full effects of the agonist and GPCR (Price et al., 1999). Figure 6A shows recordings from individual $\mathrm{D}_{2}+$ and $\mathrm{D}_{1}+\mathrm{MSNs}$ with quinpirole $(10 \mu \mathrm{M})$ application. The $\mathrm{D}_{2}$-like agonist decreased the $\mathrm{D}_{2}+$ BMR-sensitive tonic current after 5 min of application without significantly affecting the tonic current in the $\mathrm{D}_{1}+\mathrm{MSN}$. In a dual recording, SKF$81297(10 \mu \mathrm{M})$ induced a BMR-sensitive tonic current in the $\mathrm{D}_{1}+\mathrm{MSN}$ but also slightly decreased the $\mathrm{D}_{2}+$ tonic current as well (Fig. 6B). As summarized in Figure $6 C, \mathrm{D}_{2}$ receptor stimulation, and probable blockade of PKA phosphorylation, decreased tonic currents in $\mathrm{D}_{2}+\mathrm{MSNs}$, whereas $\mathrm{D}_{1}$ receptor stimulation, and promotion of PKA phosphorylation, induced tonic currents in $\mathrm{D}_{1}+\mathrm{MSNs}$. These drugs were specific for their associated dopamine receptor as application did not alter tonic currents in the opposing cell type (Fig. 6C). Therefore, GABA tonic conductance in both $\mathrm{D}_{2}+$ and $\mathrm{D}_{1}+$ MSNs is under dopamine control, presumably via a PKA phosphorylation cascade that affects $\beta 3$-containing $\mathrm{GABA}_{\mathrm{A}}$ receptors.

Because temperature may affect phosphorylation function and rates, we repeated these experiments with the $\mathrm{D}_{2}$ and $\mathrm{D}_{1}$ receptor agonists at more physiological temperatures $\left(32^{\circ} \mathrm{C}\right)$. As reported previously (Ade et al., 2008), tonic current was still significantly larger in $\mathrm{D}_{2}+$ than $\mathrm{D}_{1}+$ MSNs in these conditions. At this temperature, application of quinpirole $(10 \mu \mathrm{M})$ on $\mathrm{D}_{2}+$ neurons decreased BMR-sensitive tonic current to $38 \pm 19 \%(n=3)$ of control, whereas BMR sensitive tonic current was increased by SKF-81297 in $\mathrm{D}_{1}+$ neurons to $184 \pm 34 \%(n=3)$ of control. At room temperature, quinpirole reduced $\mathrm{D}_{2}+$ tonic current to $39 \pm 10 \%(n=5)$ of control, and SKF-81297 increased $\mathrm{D}_{1}+$ tonic current to $274 \pm 32 \%(n=4)$ of control. Therefore, phosphorylation cascades remain intact at more physiological temperatures and elicit similar effects as at room temperature.

To confirm that the $\mathrm{D}_{1}+\mathrm{MSN}$ tonic current seen with SKF-81297 application is attributable to extrasynaptic $\beta 3$-containing $\mathrm{GABA}_{\mathrm{A}}$ receptors, we applied etomidate $(3 \mu \mathrm{M})$ in these conditions. Figure $6 E$ shows currents from a $\mathrm{D}_{1}+$ neuron with etomidate application before and during coapplication with SKF-81297. When coapplied with the $\mathrm{D}_{1}$ agonist, etomidate produced a significantly greater response than when it was applied alone (etomidate, $8.3 \pm 2.2 \mathrm{pA}$; SKF-81297 plus etomidate, $16 \pm 4.2 \mathrm{pA} ; n=4 ; p<0.05$ ). These data support the hypothesis that tonic current in $\mathrm{D}_{1}+$ cells induced by SKF- 81297 is mediated through $\beta 3$-containing receptors.

It has recently been suggested that GABA tonic currents are not present in $\mathrm{D}_{2}+$ or $\mathrm{D}_{1}+\mathrm{MSN}$ in older mice (Gertler et al., 2008), suggesting that dopamine and phosphorylation may play different roles in adult mice. We tested for tonic currents in older mice and investigated their modulation through dopamine receptors. We observed BMR-sensitive tonic currents in both $\mathrm{D}_{2}+$ and $\mathrm{D}_{1}+$ MSN in animals between p33 and p37, although the magnitude was reversed compared with younger animals. $\mathrm{D}_{2}+$ MSNs averaged $8.3 \pm 3.1 \mathrm{pA}$ tonic current $(n=4 ; p<0.05$ 
compared with younger animals), whereas $\mathrm{D}_{1}+\mathrm{MSN}$ averaged $18.3 \pm 1.2 \mathrm{pA}$ tonic current $(n=6 ; p<0.05$ compared with younger animals), suggesting that dopaminergic tone may change through development. Thus, we investigated the effects of specific dopamine receptor antagonists sulpiride $(2 \mu \mathrm{M})$ and SCH $23390(10 \mu \mathrm{M})$ in $\mathrm{D}_{2}+$ and $\mathrm{D}_{1}+$ MSNs from these older animals. With their respective antagonists, tonic current increased to $14.7 \pm 1.5 \mathrm{pA}$ in three $\mathrm{D}_{2}+\mathrm{MSN}$ and $26.4 \pm 1.7 \mathrm{pA}$ in four $\mathrm{D}_{1}+\mathrm{MSNs}$, supporting a change in dopaminergic tone. To determine whether PKA phosphorylation also mediates tonic current in older animals, we supplemented $\mathrm{PKI}$ into the $\mathrm{CsCl}$ internal and saw a significant reduction in $\mathrm{D}_{1}+$ tonic current $(6 \pm 1.8 \mathrm{pA}, n=4 ; p<0.0005)$ in these older mice compared with normal internal conditions. Internal PKI application did not change the tonic current in four $\mathrm{D}_{2}+$ cells from older animals.

To determine dopamine's modulatory role on phasic $\mathrm{GABA}_{\mathrm{A}}$ receptors, we analyzed sIPSCs before and after agonist application (TTX was not applied so as to not block tonic current). Although both quinpirole and SKF-81297 tended to increase the decay time in the $\mathrm{D}_{2}+$ and $\mathrm{D}_{1}+\mathrm{MSN}$, respectively, the results were not significant (Fig. 6D). In combination with the etomidate results, these data suggest that $\mathrm{D}_{2}+$ and $\mathrm{D}_{1}+\mathrm{MSN}$ synaptic receptor populations include both $\beta 1$ - and $\beta 3$ subunit containing receptors. Because we show here that dopamine modulates GABA tonic currents and our previous study showed that GABA tonic currents control cell excitability (Ade et al., 2008), we tested dopamine's effects on rheobase and firing frequency in MSNs. In a series of current-clamp experiments, we injected increasing depolarizing current steps from a membrane potential of $-70 \mathrm{mV}$ before and after $\mathrm{D}_{2}$ and $\mathrm{D}_{1}$ agonist application (Fig. $7 A, B$ ). As previously reported, $\mathrm{D}_{1}+$ MSNs had significantly higher rheobase currents than $\mathrm{D}_{2}+$ MSNs (Ade et al., 2008; Gertler et al., 2008). Quinpirole (10 $\mu \mathrm{M}$ ) significantly increased the rheobase and significantly decreased the firing frequency in $\mathrm{D}_{2}+$ cells (Fig. $7 D$ ). In contrast, no differences in rheobase current or firing frequency were observed with SKF-81297 $(10 \mu \mathrm{M})$ application (Fig. $7 B, C, E)$. These results suggest that $D_{2}+$ cells are more excitable than $D_{1}+$ cells but that $D_{2}$ agonists decrease cell excitability, possibly because of their interactions with GABA tonic currents, as shown by the sensitivity of rheobase to BMR.

Etomidate's direct activation of GABA channels in $\mathrm{D}_{2}+$ but not $\mathrm{D}_{1}+$ MSNs suggested that tonic conductance in $\mathrm{D}_{2}+$ neurons was attributable to the presence of extrasynaptic $\beta 3$ containing $\mathrm{GABA}_{\mathrm{A}}$ receptors. However, internal PKA application and $\mathrm{D}_{1}$ dopamine receptor stimulation reveals that extrasynaptic $\beta 3$-containing receptors mediate tonic current in $\mathrm{D}_{1}+$ cells as well. Therefore, $\mathrm{D}_{1}+$ and $\mathrm{D}_{2}+\mathrm{MSN}$ both have a population of extrasynaptic $\beta 3$-containing receptors that mediate tonic current, but the important difference between the cell types is the phosphorylation state which alters the receptors' function. Thus, we speculated that in our experimental conditions, extrasynaptic receptors in $D_{1}+$ MSNs are silent and tonic current in striatal $\mathrm{D}_{2}+$ MSNs is mediated by basally phosphorylated $\beta 3$-containing receptors. This model is diagrammed with better detail in Figure 8 .

\section{Discussion}

Our previous studies revealed differential tonic conductances in $\mathrm{D}_{2}+$ and $\mathrm{D}_{1}+$ MSNs that are likely attributable to differential subunit expression (Ade et al., 2008). We investigated the role of $\alpha 1-, \alpha 5$-, and $\delta$-subunits and determined the $\alpha 5$-subunit to be a likely player in tonic conductance (Ade et al., 2008). The other two subunits that make up this functional extrasynaptic receptor remained elusive. We further investigated the $\delta$-subunit because it has been shown to be the primary mediator of tonic GABA current in other brain regions (Farrant and Nusser, 2005; Jia et 

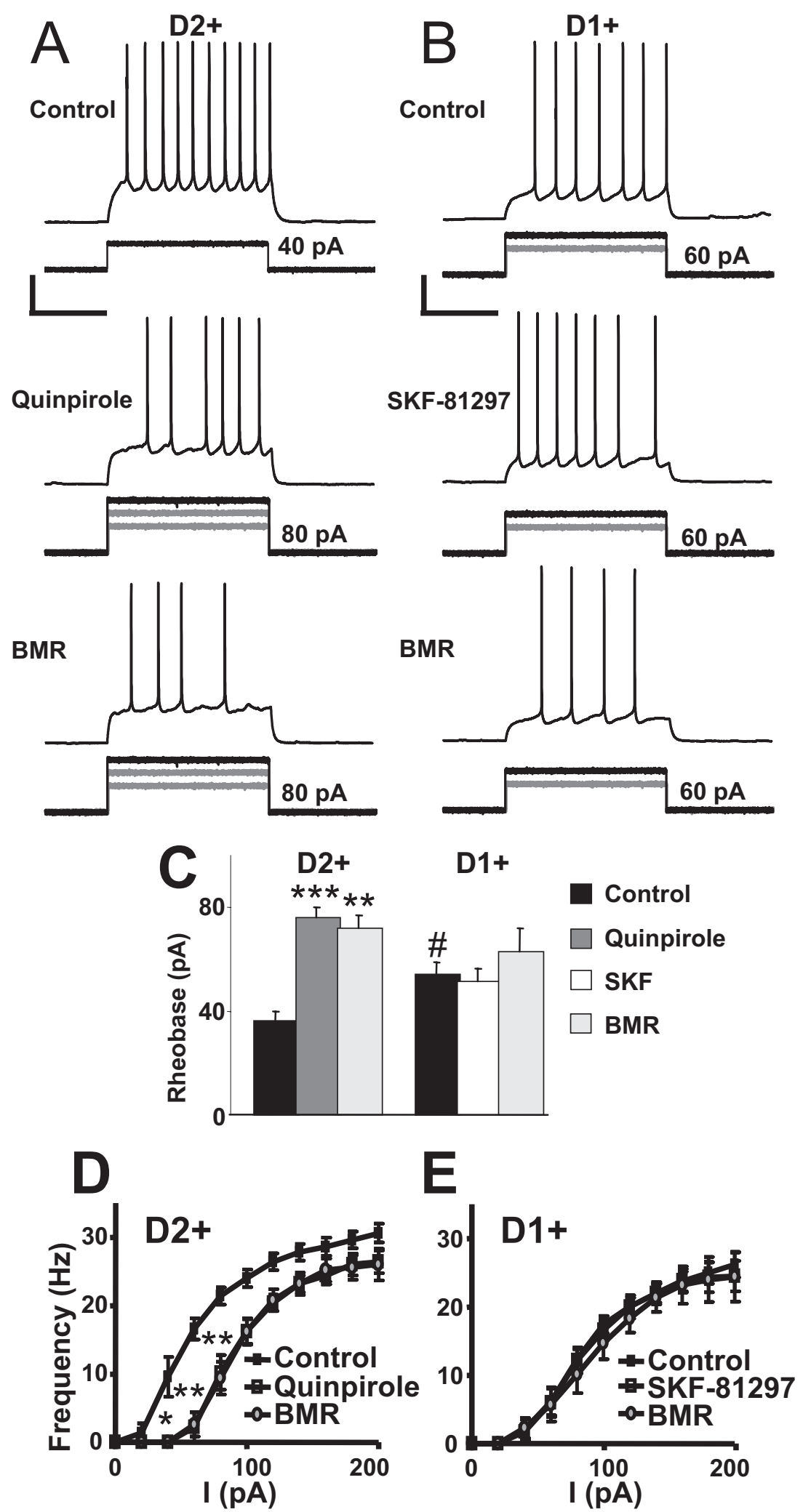

Figure 7. Dopamine modulates MSN cell excitability. $A$, Representative current-clamp recording from a $D_{2}+$ MSN illustrating the responses to a series of depolarizing current injections ( $20 \mathrm{pA} \mathrm{steps)} \mathrm{from}-70 \mathrm{mV}$, recorded with K-gluconate internal in the absence and presence of quinpirole $(10 \mu \mathrm{M})$ and $B M R(25 \mu \mathrm{M})$. $\boldsymbol{B}$, Representative example of a $D_{1}+M S N$ in the same conditions as $A$, but with the $D_{1}$-like selective agonist, SKF-81297 (10 $\left.\mu \mathrm{M}\right)$. C, Summary plot showing the averaged rheobase current in $D_{2}+$ $(n=5)$ and $D_{1}+(n=7)$ MSNs with dopamine agonist and BMR application. $\boldsymbol{D}$, Summary of action potential firing frequency in response to increasing depolarizing current injections recorded with K-gluconate internal solution in $D_{2}+$ MSNs $(\boldsymbol{\square})$ in the

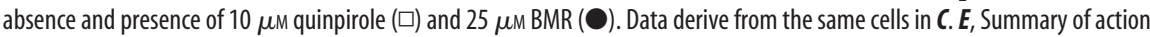
potential firing frequency in $D_{1}+$ MSNs $(\square)$ in the absence and presence of $10 \mu \mathrm{m}$ SKF-81297 ( $\square$ ) and $25 \mu \mathrm{M}$ BMR $(\mathbf{O})$. *Significance to $\mathrm{D}_{2}+$ control cells; ${ }^{\#}$ significance between $\mathrm{D}_{2}+$ and $\mathrm{D}_{1}+$ cells. Calibration: $20 \mu \mathrm{m}, 500 \mathrm{~ms}$.

al., 2005; Glykys et al., 2008). Although our previous study demonstrated that striatal $\mathrm{GABA}_{\mathrm{A}}$ receptors contain the $\delta$-subunit in both MSN subtypes (Ade et al., 2008), we discovered that the pattern of tonic conductance in a $\delta-/-$ mouse matched that from $\mathrm{BAC} \mathrm{D}_{2}$ EGFP mice. This finding is similar to those obtained with $\alpha 1-/-$ mice, suggesting that although $\alpha 1$ - and $\delta$-subunits are part of striatal $\mathrm{GABA}_{\mathrm{A}}$ receptors, they do not underlie the differences observed between $\mathrm{D}_{1}+$ and $\mathrm{D}_{2}+$ MSNs (Ade et al., 2008).

We used the general anesthetic etomidate to better ascertain MSN $\beta$-subunit expression but first verified its efficacy as a modulator and activator of GABA channels using striatally relevant recombinant receptors in HEK 293 cells. We confirmed reported selectivity of etomidate on direct activation of recombinant $\beta 3$-containing $\mathrm{GABA}_{\mathrm{A}}$ receptors with all $\alpha$-subunits tested (Hill-Venning et al., 1997). However, etomidate-mediated GABA potentiation was not significantly different between $\alpha 5 \beta 3-$ and $\alpha 5 \beta 1$-containing receptors. This contrasted with results obtained with $\alpha 2 \beta 3$ - and $\alpha 2 \beta 1$-containing receptors, where etomidate's potentiating role retained $\beta$-subunit specificity. These findings were necessary to interpret etomidate's effects on GABA currents in MSNs in striatal slice preparations. The stronger action of etomidate in $\mathrm{D}_{2}+$ cells indicated that the $\beta 3$-subunit is more abundant in $\mathrm{D}_{2}+$ than $\mathrm{D}_{1}+$ neurons. Low concentrations of exogenous GABA activated current in both $\mathrm{D}_{2}+$ and $\mathrm{D}_{1}+\mathrm{MSNs}$, and this current was potentiated by etomidate in both cell types, although the potentiation was significantly greater in $\mathrm{D}_{2}+$ neurons.

Internal PKA application induced etomidate responses and tonic conductance in $\mathrm{D}_{1}+$ neurons, suggesting that although $\mathrm{D}_{2}+$ and $\mathrm{D}_{1}+$ neurons have similar populations of $\beta 3$-containing receptors, their difference in tonic conductance is attributable to the $\beta 3$-subunit phosphorylation state. Together with previous studies that suggest phosphorylation increases currents through $\beta 3$-subunits (McDonald et al., 1998; Nusser et al., 1999; FloresHernandez et al., 2000), these data suggest that tonic current in $\mathrm{D}_{1}+$ MSNs is mediated, in part, through $\beta 3$-containing receptors.

Internal PKA application decreased tonic current in $\mathrm{D}_{2}+$ cells, implying that GABA receptors on $\mathrm{D}_{2}+$ neurons also include the $\beta 1$-subunit and/or are basally phosphorylated by an endogenous kinase, either PKA or PKC. Although speculative, too much kinase activity may alter the sta- 


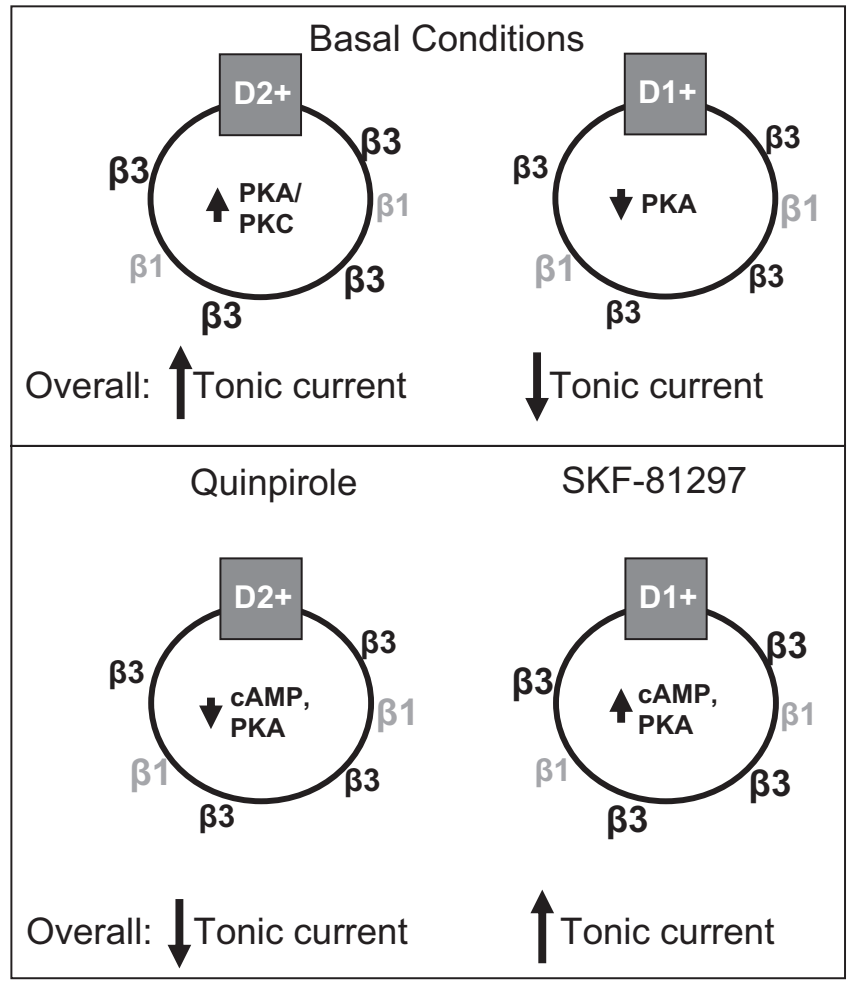

Figure 8. Tonic conductance is mediated through a phosphorylated $\beta 3$-subunit. Under basal conditions (little to no dopamine), $D_{2}$ receptors do not activate the $G_{i / 0}$ protein to inhibit PKA phosphorylation, and the $\beta 1$ - and $\beta 3$-subunits are basally phosphorylated. Because the phosphorylated $\beta 3$-subunityields increased currents and may be more plentiful than extrasynaptic $\beta 1$-subunits, $D_{2}+$ MSN display tonic current. Without dopamine, $D_{1}$ receptors do not activate the $G_{s} / G_{\text {olf }}$ protein to promote PKA phosphorylation, and the dephosphorylated $\beta 3$ subunits do not mediate increased conductance, resulting in smaller tonic current in the $D_{1}+$ than the $D_{2}+M S N$. More abundant $\beta 1$-subunit expression in $D_{1}+$ MSNs results in increased current only during GABA application. When stimulated, the $D_{2}$ receptor activates the $G_{i / o}$ protein to inhibit PKA activity, dephosphorylating the $\beta 1 / \beta 3$-subunits. A dephosphorylated $\beta 3$-subunit results in smaller tonic currents compared with basal conditions. During $D_{1}$ stimulation, the $G_{s} / G_{\text {off }}$ protein activates cAMP and PKA pathways to phosphorylate the $\beta 3$-subunit and increase tonic currents.

bility of receptors in the membrane. While we do not know the mechanism that underlies PKA's effect on the decreased $\mathrm{D}_{2}+$ tonic current, basally phosphorylated $\beta 3$-containing receptors have been found in the hippocampus (Brandon et al., 2000) and cortex (Kumar et al., 2005), and results from both studies suggested that $\mathrm{PKC}$ is responsible for the basal phosphorylation (Kittler and Moss, 2003). Indeed, internal PKI application decreased $\mathrm{D}_{2}+$ tonic current, suggesting that $\mathrm{D}_{2}+$ MSN tonic current is under basal PKA modulation. Further studies, including biochemical analysis, are needed to verify a basally phosphorylated $\beta 3$-subunit in $\mathrm{D}_{2}+$ neurons.

Our results with dopamine antagonists propose that striatal dopamine is not present in our slice preparation in young mice, and therefore both dopamine receptors remain inactive (Lee et al., 2001). Activation of $D_{1}$ receptors in striatonigral neurons stimulates PKA activity, whereas activation of $\mathrm{D}_{2}$ receptors in striatopallidal MSNs inhibits PKA activity (Stoof and Kebabian, 1984). As modeled in Figure 8 , the $D_{1}$ receptor agonist SKF81297 induces tonic currents in $\mathrm{D}_{1}+$ cells possibly through phosphorylated extrasynaptic $\beta 3$-containing receptors. On the contrary, $\mathrm{D}_{2}+$ tonic conductance decreases when the $\mathrm{D}_{2}+$ agonist quinpirole is applied, suggesting a role for dephosphorylated $\beta 3$ containing $\mathrm{GABA}_{\mathrm{A}}$ receptors. However, quinpirole did not abol- ish the tonic current, offering a role for $\beta 1$-containing receptors in $\mathrm{D}_{2}+$ neurons or suggesting that the remaining current is via the $\alpha 5$-subunit that mediates tonic current, even without enhanced function through phosphorylated $\beta 3$-subunits. The lack of tonic current in $\mathrm{D}_{1}+$ cells may also be related to more abundant expression of $\alpha 2 \beta 1$-containing receptors, supported by HEK 293 cells that showed higher sensitivity to GABA in $\alpha 2 \beta 3$ containing receptors than $\alpha 2 \beta 1$-containing receptors. The relative abundance of $\beta 1$ - and $\beta 3$-subunits, combined with $\alpha 2$ - or $\alpha 5$-subunits, together with distinct dopamine receptor mediated phosphorylation/dephosphorylation, regulates tonic GABA conductance in striatal MSNs.

Our results with dopamine agonists on tonic current were obtained without TTX and with an intact striatal network that includes several types of GABAergic interneurons as well as cholinergic interneurons (Tepper et al., 2004), which may contribute to the effects we see with dopamine-selective agonists on the opposing cell type. We cannot exclude that some of the dopamine agonist effects are attributable to a presynaptic mechanism. Because results with dopamine receptor activation and internal PKA application were similar, we suggest that dopamine's effects are primarily postsynaptic and dependent upon PKA activity.

We previously showed that differential extrasynaptic $\alpha 5$ subunit function contributes to $\mathrm{D}_{2}+$ tonic conductance (Ade et al., 2008). Therefore, $\mathrm{D}_{2}+$ neurons may have an extrasynaptic population of $\alpha 5 \beta 3$-containing receptors. As $\mathrm{D}_{1}+$ neurons lack the $\alpha 5$-subunit, tonic conductance in these neurons is most likely mediated via the phosphorylated $\beta 3$-subunit together with the $\alpha 2$-subunit. Although etomidate's potentiating effect was specific for $\alpha 2 \beta 3$-containing receptors, the effects did not differ between $\alpha 5 \beta 1$ - and $\alpha 5 \beta 3$-containing receptors. Tonic current is potentiated by etomidate in $\mathrm{D}_{2}+\mathrm{MSNs}$ because they express $\alpha 5 \beta 3$-containing receptors. In contrast, $\alpha 2 \beta 1$-containing receptors are more abundant than $\alpha 2 \beta 3$-containing receptors in $\mathrm{D}_{1}+$ MSNs, and the potentiating effect of etomidate is smaller than in $\mathrm{D}_{2}+$ MSNs.

Although etomidate, internal PKA application, and dopamine agonists induced significant changes to $\mathrm{D}_{2}+$ and $\mathrm{D}_{1}+\mathrm{MSN}$ tonic currents, these actions failed to significantly alter synaptic currents. These results indicate that $\mathrm{D}_{2}+$ and $\mathrm{D}_{1}+\mathrm{MSN}$ have similar synaptic receptor populations that include both $\beta 1$ - and $\beta 3$ subunits. However, as both $\beta 1$ - and $\beta 3$-subunits are regulated by PKA and dopamine, it remains to be clarified why these agents fail to alter IPSCs in MSNs. One possible hypothesis suggests that synaptic receptors are composed of complementary amounts of $\beta 1$ - and $\beta 3$-subunits, and therefore their differential regulation by these agents is countered. Previous studies into dopamine's modulatory role on inhibitory transmission found that dopamine does not modulate IPSCs in the rat dorsal striatum, although it does affect IPSCs in the ventral striatum (Nicola and Malenka, 1998). By exclusively modulating tonic, and not phasic, currents in the dorsal striatum, dopamine may regulate cell excitability.

Dopamine has been shown to modulate cell excitability in several animal models and brain regions through a variety of different mechanisms (Belousov and van den Pol, 1997; Ding and Perkel, 2002; Yasumoto et al., 2002; Perez et al., 2006). We show that dopamine agonists modulate rheobase current and functionally decrease the cell excitability in $\mathrm{D}_{2}+$ cells without affecting excitability in $\mathrm{D}_{1}+$ cells. Dopamine modulates many ion channels in MSNs such as $\mathrm{Ca}^{2+}$ and inward rectifier $\mathrm{K}^{+}$channels (Moyer et al., 2007). One computational model showed that dopamine decreases the excitability of $\mathrm{D}_{2}+\mathrm{MSNs}$, while increasing 
the excitability in $\mathrm{D}_{1}+$ MSNs independently of GABA tonic conductance (Moyer et al., 2007). Previous results from our lab showed that GABA tonic conductance facilitates MSN cell excitability (Ade et al., 2008). In the present study, BMR did not change rheobase current in $\mathrm{D}_{2}+$ cells after quinpirole application, suggesting that changes in cell excitability with quinpirole application are mediated through GABA receptors. We suggest that this modulation of GABA tonic currents may support other mechanisms of dopamine modulation for cell excitability.

It has recently been suggested that GABA tonic currents are not present and do not contribute to the different excitabilities between the two types of MSNs in older mice (Gertler et al., 2008). In our study, we observed tonic conductance in both cell types from older mice. These opposing results may be explained by experimental conditions like extracellular $\mathrm{K}^{+}$concentrations which may alter ambient GABA concentrations by modulating interneuron activity. Tonic currents in both MSN subtypes from older mice had opposite magnitudes, which were also modulated by PKA. In these mice, the action of specific dopamine receptor antagonists on tonic current suggests a possible role for increased ambient dopamine but will require further investigation.

The results presented here suggest a target for striatal GABAergic tonic conductance in MSNs. We posit that a basally phosphorylated $\beta 3$-subunit is responsible for the $\mathrm{D}_{2}+$ tonic conductance but show that internal PKA application or $\mathrm{D}_{1}$ agonist application reveals extrasynaptic $\beta 3$-containing receptors that mediate tonic current in $\mathrm{D}_{1}+$ cells (Fig. 8). Because Parkinson's disease symptoms arise from an imbalance between $\mathrm{D}_{1}+$ striatonigral projection and $\mathrm{D}_{2}+$ striatopallidal projection outputs (Mallet et al., 2006), a selective target of tonic conductance in striatonigral or striatopallidal pathways offers potential therapeutic benefits in alleviating debilitating motor control symptoms.

\section{References}

Ade KK, Janssen MJ, Ortinski PI, Vicini S (2008) Differential tonic GABA conductances in striatal medium spiny neurons. J Neurosci 28:1185-1197.

Belelli D, Callachan H, Hill-Venning C, Peters JA, Lambert JJ (1996) Interaction of positive allosteric modulators with human and Drosophila recombinant GABA receptors expressed in Xenopus laevis oocytes. Br J Pharmacol 118:563-576.

Belousov AB, van den Pol AN (1997) Dopamine inhibition: enhancement of GABA activity and potassium channel activation in hypothalamic and arcuate nucleus neurons. J Neurophysiol 78:674-688.

Brandon NJ, Delmas P, Kittler JT, McDonald BJ, Sieghart W, Brown DA, Smart TG, Moss SJ (2000) GABAA receptor phosphorylation and functional modulation in cortical neurons by a protein kinase C-dependent pathway. J Biol Chem 275:38856-38862.

Brown N, Kerby J, Bonnert TP, Whiting PJ, Wafford KA (2002) Pharmacological characterization of a novel cell line expressing human $\alpha 4 \beta 3 \delta$ $\mathrm{GABA}_{\mathrm{A}}$ receptors. Br J Pharmacol 136:965-974.

Chen G, Kittler JT, Moss SJ, Yan Z (2006) Dopamine $D_{3}$ receptors regulate $\mathrm{GABA}_{\mathrm{A}}$ receptor function through a phospho-dependent endocytosis mechanism in nucleus accumbens. J Neurosci 26:2513-2521.

Cheng VY, Martin LJ, Elliott EM, Kim JH, Mount HT, Taverna FA, Roder JC, Macdonald JF, Bhambri A, Collinson N, Wafford KA, Orser BA (2006) $\alpha 5 \mathrm{GAGA}_{\mathrm{A}}$ receptors mediate the amnestic but not sedative-hypnotic effects of the general anesthetic etomidate. J Neurosci 26:3713-3720.

Day M, Wang Z, Ding J, An X, Ingham CA, Shering AF, Wokosin D, Ilijic E, Sun Z, Sampson AR, Mugnaini E, Deutch AY, Sesack SR, Arbuthnott GW, Surmeier DJ (2006) Selective elimination of glutamatergic synapses on striatopallidal neurons in Parkinson's disease models. Nat Neurosci 9:251-259.

Ding L, Perkel DJ (2002) Dopamine modulates excitability of spiny neurons in the avian basal ganglia. J Neurosci 22:5210-5218.

Farrant M, Nusser Z (2005) Variations on an inhibitory theme: phasic and tonic activation of $\mathrm{GABA}_{\mathrm{A}}$ receptors. Nat Rev Neurosci 6:215-229.

Flores-Hernandez J, Hernandez S, Snyder GL, Yan Z, Fienberg AA, Moss SJ,
Greengard P, Surmeier DJ (2000) D1 dopamine receptor activation reduces $\mathrm{GABA}_{\mathrm{A}}$ receptor currents in neostriatal neurons through a PKA/ DARPP-32/PP1 signaling cascade. J Neurophysiol 83:2996-3004.

Fritschy JM, Mohler H (1995) GABA $_{\mathrm{A}}$-receptor heterogeneity in the adult rat brain: differential regional and cellular distribution of seven major subunits. J Comp Neurol 359:154-194.

Gerfen CR, Engber TM, Mahan LC, Susel Z, Chase TN, Monsma FJ Jr, Sibley DR (1990) D1 and D2 dopamine receptor-regulated gene expression of striatonigral and striatopallidal neurons. Science 250:1429-1432.

Gertler TS, Chan CS, Surmeier DJ (2008) Dichotomous anatomical properties of adult striatal medium spiny neurons. J Neurosci 28:10814-10824.

Glykys J, Mody I (2007) The main source of ambient GABA responsible for tonic inhibition in the mouse hippocampus. J Physiol 582:1163-1178.

Glykys J, Mann EO, Mody I (2008) Which GABA $_{\mathrm{A}}$ receptor subunits are necessary for tonic inhibition in the hippocampus? J Neurosci 28:1421-1426.

Gong S, Zheng C, Doughty ML, Losos K, Didkovsky N, Schambra UB, Nowak NJ, Joyner A, Leblanc G, Hatten ME, Heintz N (2003) A gene expression atlas of the central nervous system based on bacterial artificial chromosomes. Nature 425:917-925.

Herd MB, Haythornthwaite AR, Rosahl TW, Wafford KA, Homanics GE, Lambert JJ, Belelli D (2008) The expression of GABAA beta subunit isoforms in synaptic and extrasynaptic receptor populations of mouse dentate gyrus graule cells. J Physiol 586:989-1004.

Hevers W, Lüddens H (2002) Pharmacological heterogeneity of gammaaminobutyric acid receptors during development suggests distinct classes of rat cerebellar granule cells in situ. Neuropharmacology 42:34-47.

Hill-Venning C, Belelli D, Peters JA, Lambert JJ (1997) Subunit-dependent interaction of the general anaesthetic etomidate with the gammaaminobutyric acid type A receptor. Br J Pharmacol 120:749-756.

Jia F, Pignataro L, Schofield CM, Yue M, Harrison NL, Goldstein PA (2005) An extrasynaptic GABAA receptor mediates tonic inhibition in thalamic VB neurons. J Neurophysiol 94:4491-4501.

Kittler JT, Moss SJ (2003) Modulation of GABAA receptor activity by phsophorylation and receptor trafficking: implications for the efficacy of synaptic inhibition. Curr Opin Neurobiol 13:341-347.

Kittler JT, Chen G, Honing S, Bogdanov Y, McAinsh K, Arancibia-Carcamo IL, Jovanovic JN, Pangalos MN, Haucke V, Yan Z, Moss SJ (2005) Phospho-dependent binding of the clathrin AP2 adaptor complex to GABAA receptors regulates the efficacy of inhibitory synaptic transmission. Proc Natl Acad Sci U S A 102:14871-14876.

Kumar S, Khisti RT, Morrow AL (2005) Regulation of native GABAA receptors by $\mathrm{PKC}$ and protein phosphatase activity. Psychopharmacology (Berl) 183:241-247.

Lee BC, Bing G, Jhoo WK, Yoon JM, Kang KS, Shin EJ, Kim WK, Ko KH, Kim HC (2001) Prenatal exposure to magnetic field increases dopamine levels in the striatum of offspring. Clin Exp Pharmacol Physiol 28:884-886.

Mallet N, Ballion B, Le Moine C, Gonon F (2006) Cortical inputs and GABA interneurons imbalance projection neurons in the striatum of parkinsonian rats. J Neurosci 26:3875-3884.

McDonald BJ, Amato A, Connolly CN, Benke D, Moss SJ, Smart TG (1998) Adjacent phosphorylation sites on $\mathrm{GABA}_{\mathrm{A}}$ receptor $\beta$ subunits determine regulation by cAMP-dependent protein kinase. Nat Neurosci 1:23-28.

Mihalek RM, Banerjee PK, Korpi ER, Quinlan JJ, Firestone LL, Mi ZP, Lagenaur C, Tretter V, Sieghart W, Anagnostaras SG, Sage JR, Fanselow MS, Guidotti A, Spigelman I, Li Z, DeLorey TM, Olsen RW, Homanics GE (1999) Attenuated sensitivity to neuroactive steroids in gammaaminobutyrate type A receptor delta subunit knockout mice. Proc Natl Acad Sci U S A 96:12905-12910.

Moss SJ, Smart TG, Blackstone CD, Huganir RL (1992) Functional modulation of $\mathrm{GABA}_{\mathrm{A}}$ receptors by cAMP-dependent protein phosphorylation. Science 257:661-665.

Moyer JT, Wolf JA, Finkel LH (2007) Effects of dopaminergic modulation on the integrative properties of the ventral striatal medium spiny neuron. J Neurophysiol 98:3731-3748.

Murase K, Ryu PD, Randic M (1989) Excitatory and inhibitory amino acids and peptide-induced responses in acutely isolated rat spinal dorsal horn neurons. Neurosci Lett 103:56-63.

Nicola SM, Malenka RC (1998) Modulation of synaptic transmission by dopamine and norepinephrine in ventral but not dorsal striatum. J Neurophysiol 79:1768-1776.

Nusser Z, Sieghart W, Mody I (1999) Differential regulation of synaptic 
GABAA receptors by cAMP-dependent protein kinase in mouse cerebellar and olfactory bulb neurons. J Physiol 521:421-435.

Perez MF, White FJ, Hu XT (2006) Dopamine D2 receptor modulation of $\mathrm{K}+$ channel activity regulates excitability of nucleus accumbens neurons at different membrane potentials. J Neurophysiol 96:2217-2228.

Pirker S, Schwarzer C, Wieselthaler A, Sieghart W, Sperk G (2000) GABA(A) receptors: immunocytochemical distribution of 13 subunits in the adult rat brain. Neuroscience 101:815-850.

Price CJ, Kim P, Raymond LA (1999) D1 dopamine receptor-induced cyclic AMP-dependent protein kinase phosphorylation and potentiation of striatal glutamate receptors. J Neurochem 73:2441-2446.

Sanna E, Murgia A, Casula A, Biggio G (1997) Differential subunit dependence of the actions of the general anesthetics alphaxalone and etomidate at gamma-aminobutyric acid type A receptors expressed in Xenopus laevis oocytes. Mol Pharmacol 51:484-490.

Schwarzer C, Berresheim U, Pirker S, Wieselthaler A, Fuchs K, Sieghart W, Sperk G (2001) Distribution of the major gamma-aminobutyric $\operatorname{acid}_{A}$ receptor subunits in the basal ganglia and associated limbic brain areas of the adult rat. J Comp Neurol 433:526-549.
Slany A, Zezula J, Fuchs K, Sieghart W (1995) Allosteric modulation of $[3 \mathrm{H}]$ flunitrazepam binding to recombinant GABAA receptors. Eur J Pharmacol 291:99-105.

Stoof JC, Kebabian JW (1984) Two dopamine receptors: biochemistry, physiology and pharmacology. Life Sci 35:2281-2296.

Taverna S, Ilijic E, Surmeier DJ (2008) Recurrent collateral connections of striatal medium spiny neurons are disrupted in models of Parkinson's disease. J Neurosci 28:5504-5512.

Tepper JM, Koós T, Wilson CJ (2004) GABAergic microcircuits in the neostriatum. Trends Neurosci 27:662-669.

Venance L, Glowinski J (2003) Heterogeneity of spike frequency adaptation among medium spiny neurones from the rat striatum. Neuroscience 122:77-92.

Yan Z, Surmeier DJ (1997) D5 dopamine receptors enhance Zn2+ -sensitive GABA(A) currents in striatal cholinergic interneurons through a PKA/PP1 cascade. Neuron 19:1115-1126.

Yasumoto S, Tanaka E, Hattori G, Maeda H, Higashi H (2002) Direct and indirect actions of dopamine on the membrane potential in medium spiny neurons of the mouse neostriatum. J Neurophysiol 87:1234-1243. 